\title{
VEGFB Gene
}

National Cancer Institute

\section{Source}

National Cancer Institute. VEGFB Gene. NCI Thesaurus. Code C105596.

This gene plays a role in regulation of blood vessel physiology. 